Full-length article

\title{
Onychin inhibits proliferation of vascular smooth muscle cells by regulating cell cycle ${ }^{1}$
}

\author{
Ming YANG ${ }^{2}$, Hong-lin $\mathrm{HUANG}^{2}$, Bing-yang ZHU, Qin-hui TUO, Duan-fang LIAO \\ Institute of Pharmacy and Pharmacology, Nanhua University, Hengyang 421001, China
}

\section{Key words}

onychin; vascular smooth muscle; cell cycle; retinoblastoma; cyclin $\mathrm{D}_{1}$; cyclin $\mathrm{E}$; tyrosine kinase; mitogen-activated protein kinase

\footnotetext{
${ }^{1}$ Project supported by grants from the State Key Basic Research and Development Program of China (973: No G2000056905), the National Natural Science Foundation of China (No 39970847, 30171084), and the Natural Science Foundation of Hunan (No 03JJY3037).

${ }^{2}$ These two authors contributed equally to the paper.

${ }^{3}$ Correspondence to Prof Duan-fang LIAO, MD, PhD.

Phn 86-734-828-1308.

Fax 86-734-828-1239.

E-maildfliao66@yahoo.com.cn
}

Received 2004-09-20

Accepted 2004-11-15

doi: $10.1111 / \mathrm{j} .1745-7254.2005 .00026 . \mathrm{x}$

\begin{abstract}
Aim: To investigate the effects of onychin on the proliferation of cultured rat artery vascular smooth muscle cells (VSMCs) in the presence of 10\% new-born calf serum (NCS). Methods: Rat VSMCs were incubated with onychin 1-50 $\mu \mathrm{mol} / \mathrm{L}$ or genistein $10 \mu \mathrm{mol} / \mathrm{L}$ in the presence of $10 \% \mathrm{NCS}$ for $24 \mathrm{~h}$. The proliferation of VSMCs was measured by cell counting and MTS/PMS colorimetric assays. Cell cycle progression was evaluated by flow cytometry. Retinoblastoma $(\mathrm{Rb})$ phosphorylation, and expression of cyclin $\mathrm{D}_{1}$ and cyclin $\mathrm{E}$ were measured by Western blot assays. The tyrosine phosphorylation of ERK1/2 was examined by immunoprecipitation techniques using anti-phospho-tyrosine antibodies. Results: The proliferation of VSMCs was accelerated significantly in the presence of $10 \%$ NCS. Onychin reduced the metabolic rate of MTS and the cell number of VSMCs in the presence of $10 \%$ NCS in a dose-dependent manner. Flow cytometry analysis revealed that the $\mathrm{G}_{1}$-phase fraction ratio in the onychin group was higher than that in the $10 \%$ NCS group $(85.2 \%$ vs $70.0 \%, P<0.01)$, while the S-phase fraction ratio in the onychin group was lower than that in $10 \%$ NCS group $(4.3 \% v s$ $16.4 \%, P<0.01)$. Western blot analysis showed that onychin inhibited Rb phosphorylation and reduced the expression of cyclin $\mathrm{D}_{1}$ and cyclin $\mathrm{E}$. The effects of onychin on proliferation, the cell cycle and the expression of cyclins in VSMCs were similar to those of genistein, an inhibitor of tyrosine kinase. Furthermore immunoprecipitation studies showed that both onychin and genistein markedly inhibited the tyrosine phosphorylation of ERK $1 / 2$ induced by $10 \%$ NCS. Conclusion: Onychin inhibits the proliferation of VSMCs through $\mathrm{G}_{1}$ phase cell cycle arrest by decreasing the tyrosine phosphorylation of ERK1/2, and the expression of cyclin $\mathrm{D}_{1}$ and cyclin $\mathrm{E}$, and sequentially inhibiting $\mathrm{Rb}$ phosphorylation.
\end{abstract}

\section{Introduction}

Alterations in vascular smooth muscle cell (VSMC) proliferation plays an important role in the development of the pathological process that underlies restenosis, atherosclerosis, and vascular graft occlusion ${ }^{[1]}$. Despite intense efforts, no widely effective therapy exits for the prevention of such vascular diseases. Recently some agents have been shown to have potential value by virtue of their abilities to attenuate the proliferation of $\mathrm{VSMCs}^{[2-4]}$. Among them, genistein (4,5,7-trihydroxyisoflavone), a soybean-derived isoflavone, has been shown to inhibit platelet derived growth factor (PDGF)-induced proliferation and DNA synthesis of aortic smooth muscle cells in stroke-prone spontaneously hypertensive rats ${ }^{[5]}$. Moreover, epidemiological studies indicate that genistein has beneficial effects on cardiovascular disease $^{[6,7]}$, such as lowering total and low density lipoprotein (LDL)-cholesterol levels. More recently, onychin, a new compenent extracted from Onychin lucidum of sinopteridaceae, has attracted our interest because its structure is similar to genistein ${ }^{[8]}$. Interestingly, our previous results have shown that onychin protects the endothelium-dependent relaxation in rabbit aortic rings and inhibits oxidative stress- 
induced apoptosis of endothelial cells, which is mediated by increasing NO release, regulating expression of caveolin-1 and activation of mitogen-activated protein kinases $(\mathrm{MAPK})^{[9-13]}$. In the present study, we extend our investigation to the effects of onychin on the proliferation of rat VSMCs induced by $10 \%$ NCS.

\section{Materials and methods}

Materials Male Sprague-Dawley rats were obtained from the Experimental Animal Center of Nanhua University (Hengyang, China). Genistein, elastase, and monoclonal antibodies for $\alpha$-actins of smooth muscle cells were obtained from Sigma (St Louis, USA). Dulbecco's modified Eagle's medium (DMEM) and NCS were from GibcoBRL (Maryland, USA). The Cell Titer 96 Aqueous Non-Radioactive Cell Proliferation Assay Kit (MTS/PMS) was purchased from Promega (WI, USA). Monoclonal mouse antiERK1/2, -pTyr, -cyclin $\mathrm{D}_{1}$, -cyclin E, and polyclonal mouse anti-Rb were from Santa Cruz Biotechnology (Santa Cruz, USA).

Cell culture The thoracic aortas were isolated from the 150-200 g male Sprague-Dawley rats and cultured by using a novel enzymatic dispersion method ${ }^{[14]}$. Briefly, rat aortas were in sterile conditions removed from left subclavian origin to the point of diaphragmatic insertion. The vascular media was digested, and the cells were centrifuged and plated down in prepared flasks. VSMCs were cultivated in DMEM (containing 10\% NCS) and in a $5 \% \mathrm{CO}_{2}$ humidified-atmosphere incubator until they displayed as a typical "hill and valley" morphology. The immunohistochemistry staining with a monoclonal antibody against $\alpha$-actins showed that there were no co-cultured fibroblast cells. VSMCs from 5 to 15 passages were used for experimentation. Before mitogenic stimulation, subconfluent cells were arrested in a quiescent state with DMEM containing $0.1 \% \mathrm{NCS}$ for $48 \mathrm{~h}$.

Cell count VSMCs $\left(2.5 \times 10^{4}\right)$ were plated into a 24 -well plate and grown in DMEM supplemented with $10 \%$ NCS for $24 \mathrm{~h}$. In some experiments cells were growth-arrested by incubation in DMEM containing $0.1 \% \mathrm{NCS}$ for $48 \mathrm{~h}$ and then exposed to different concentrations of onychin before treatment with $10 \% \mathrm{NCS}$ for $24 \mathrm{~h}$ or $48 \mathrm{~h}$. Genistein (10 $\mu \mathrm{mol} / \mathrm{L}$ ) was used as the positive control. The cells were then washed with phosphate-buffered saline (PBS), trypsinized, and diluted with isotonic solution. Cells were stained with Trypane blue and the viable cells were counted using a coulter counter.

MTS assay Cell growth was measured by using MTS assay according to the manufacture's instructions. Briefly, 3-(4,5-dimethylthiazol-2-yl)-5-(3-carboxymethoxyphenyl)2-(4-sulfophenyl)-2H-tetrazolium (MTS) and phenazine methosulfate (PMS) were mixed at a ratio of 20:1 immediately before being added to the samples. The MTS/PMS solution $(20 \mu \mathrm{L})$ was added to each well of the 96 -well plate and and the plates were incubated at $37^{\circ} \mathrm{C}$ in a humidified $5 \% \mathrm{CO}_{2}$ atmosphere for $90 \mathrm{~min}$. Absorbance was read at $490 \mathrm{~nm}$ using Bio-Tek's Power Wave X reader-assay system (BIO-TEK Instruments, USA). Each sample was read in triplicate.

Flow cytometry Cells were suspended in phosphatebuffered saline (PBS, pH 7.4), and fixed with 70\% (v/v) ethanol at $-20{ }^{\circ} \mathrm{C}$ for $30 \mathrm{~min}$. After the ethanol was removed, the cells were incubated with PBS containing RNase (172 MU/L) at $37^{\circ} \mathrm{C}$ for $30 \mathrm{~min}$ and then stained for $30 \mathrm{~min}$ with $0.005 \%$ propidium iodide. Fluorescence was measured by using Epics Altra Flow Cytometer (Beckman Coulter Co, USA).

Western blot analysis After treatment, VSMCs were washed twice with cold $\left(4^{\circ} \mathrm{C}\right)$ PBS ( $\left.\mathrm{pH} 7.4\right)$ and harvested on ice in buffer A containing HEPES $20 \mathrm{mmol} / \mathrm{L}$ (pH 7.4), EDTA $2 \mathrm{mmol} / \mathrm{L}$, glycerophosphate $50 \mathrm{mmol} / \mathrm{L}$, dithiothreitol $1 \mathrm{mmol} / \mathrm{L}, \mathrm{Na}_{3} \mathrm{VO}_{4} 1 \mathrm{mmol} / \mathrm{L}, 1 \%$ Triton, $10 \%$ glycerol, leupeptin $1 \mathrm{mg} / \mathrm{L}$, aprotinin $1 \mathrm{mg} / \mathrm{L}$, and phenylmethylsulfonyl fluoride $100 \mu \mathrm{mol} / \mathrm{L}$. The suspension was incubated on ice for $20 \mathrm{~min}$ and vortexed every $5 \mathrm{~min}$. Cell lysates were then centrifuged at $13000 \mathrm{r} / \mathrm{min}$ (Eppendorf centrifuge, Osterode, Germany) for 30 min at $4{ }^{\circ} \mathrm{C}$. The supernatants were collected, and protein concentration was measured by using the Bio-Rad assay. Forty micrograms of protein $(40 \mu \mathrm{g})$ weas electrophoresed onto a $12 \%$ SDS-PAGE gel and transferred to a polyvinylidene difluoride membrane. The membrane was incubated for $1 \mathrm{~h}$ with primary antibodies followed by incubation with second antibodies (horseradish peroxidase-conjugated). Immunoactive bands were visualized using chemiluminescence (AmershamPharmacia Biotech, Piscataway, USA) and densitometric analysis was carried out using an imager and densitometer ${ }^{[15]}$.

Immunoprecipitation Growth-arrested VSMCs were exposed to $0.1 \% \mathrm{NCS}, 10 \% \mathrm{NCS}, 10 \% \mathrm{NCS}+10 \mu \mathrm{mol} / \mathrm{L}$ onychin, or $10 \% \mathrm{NCS}+10 \mu \mathrm{mol} / \mathrm{L}$ genistein for $20 \mathrm{~min}$. Cell lysates were prepared for immunoprecipitation as described previously $^{[16]}$. Briefly, equal amounts of protein $(500 \mu \mathrm{g})$ were immunoprecipitated with anti-ERK1/2 polyclonal antibodies overnight at $4{ }^{\circ} \mathrm{C}$. Immune complexes were collected by incubation with protein A-Sepharose beads for $2 \mathrm{~h}$ at $4{ }^{\circ} \mathrm{C}$. Immunoprecipitates were separated by using SDSPAGE, and proteins were detected by immunoblotting as described above using anti-pTyr monoclonal antibodies. 
Statistical analysis All values are expressed as mean \pm SD. Statistical significance was determined by oneway ANOVA. $P<0.05$ was considered significant.

\section{Results}

Effect of onychin on the proliferation of VSMCs Both cell counting and the MTS assay showed that onychin treatment for $24 \mathrm{~h}$ or $48 \mathrm{~h}$ significantly inhibited VSMC proliferation induced by $10 \%$ NCS. The inhibition was concentration-dependent with peak at $10 \mu \mathrm{mol} / \mathrm{L}$ (Table 1). The efficiency of $10 \mu \mathrm{mol} / \mathrm{L}$ onychin treatment for $24 \mathrm{~h}$ was similar to that of $10 \mu \mathrm{mol} / \mathrm{L}$ genistein. Therefore we chose $10 \mu \mathrm{mol} / \mathrm{L}$ onychin treating cells for $24 \mathrm{~h}$ in the following experiments.

Changes in the VSMC cycle induced by onychin treatment The percentages of $\mathrm{G}_{0} / \mathrm{G}_{1}$ or $\mathrm{S}$ phase cells in the $10 \%$ NCS-stimulated group were $70.0 \%$ and $16.4 \%$ respectively. In contrast, $10 \mu \mathrm{mol} / \mathrm{L}$ onychin and $10 \mu \mathrm{mol} / \mathrm{L}$ genistein treatments for $24 \mathrm{~h}$ led to a significant inhibition of DNA synthesis as evidenced by the fact that the percentages of $\mathrm{G}_{0} / \mathrm{G}_{1}$ phase cells increased to $85.2 \%$ and $\mathrm{S}$ phase cells decreased to $4.3 \%$ in the onychin group (Figure 1).

Decreased Rb phosphorylation induced by onychin treatment The cell cycle progression from $G_{1}$ to $S$ phase is usually accompanied by $\mathrm{Rb}$ phosphorylation in the late $\mathrm{G}_{1}$ phase. We therefore examined $\mathrm{Rb}$ phosphorylation in VSMCs by using Western blotting with anti-phospho Rb antibody. NCS (10\%) stimulated Rb phosphorylation markedly and onychin and genistein inhibited $\mathrm{Rb}$ phosphorylation by $70.1 \%$ and $58.8 \%$, respectively (Figure 2 ).

Onychin lowers the expression of cyclin $D_{1}$ and cyclin E To further explore the mechanism by which onychin inhibited $\mathrm{Rb}$, we examined the expression of cyclin $\mathrm{D}_{1}$ and cyclin E by Western blotting. Results showed that $10 \%$ NCS treatment significantly increased both expressions of cyclin $\mathrm{D}_{1}$ and cyclin $\mathrm{E}$ and that pretreatment with onychin $10 \mu \mathrm{mol} / \mathrm{L}$ and genistein $10 \mu \mathrm{mol} / \mathrm{L}$ decreased the NCS-induced expression of these two proteins (Figure 3, 4).

Effect of onychin on the tyrosine phosphorylation of ERK1/2 ERK1/2 activation is at upstream of cyclins. It has been reported that the protein tyrosine inhibitor genistein is able to inactivate ERK1/2. To investigate whether the inhibitory effect of onychin on ERK1/2 is mediated by tyrosine kinase inhibition, we observed the phosphorylation of the tyrosine residue in ERK1/2. When growth-arrested VSMCs were treated with $10 \%$ NCS, a marked time-dependent tyrosine phosphorylation of ERK1/2 was observed, with peak at $20 \mathrm{~min}$ (data not shown). Pretreatment with genistein, as well as onychin, significantly inhibited the $10 \%$ NCS-induced
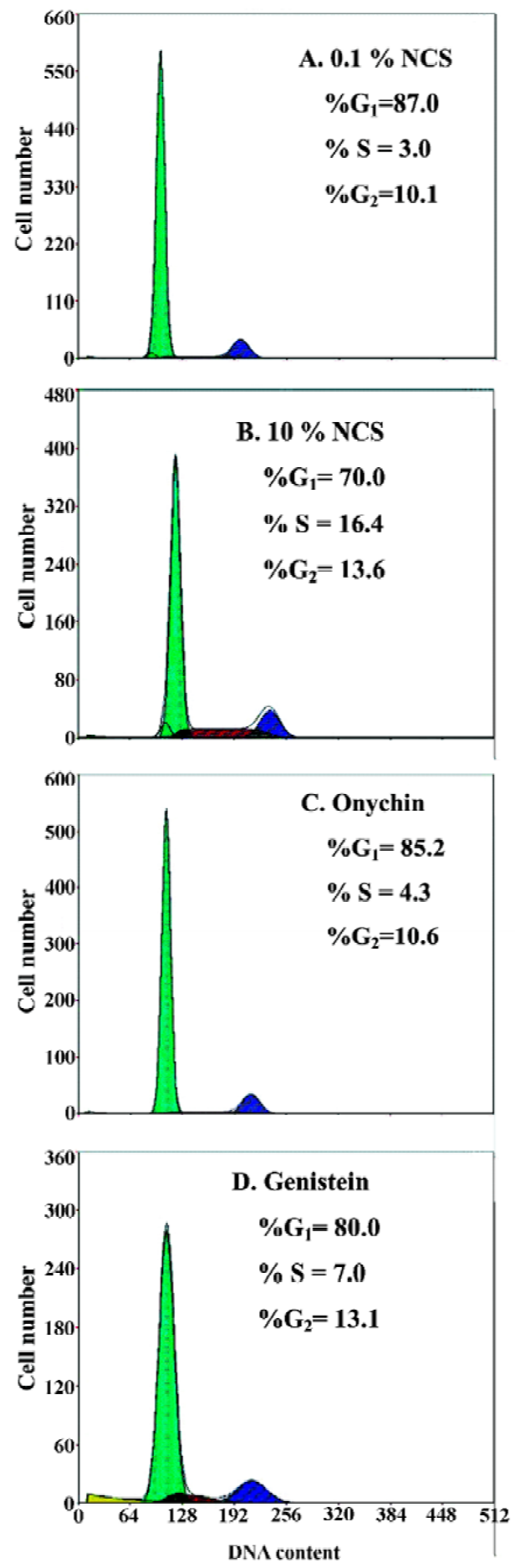

Figure 1. Effect of onychin $10 \mu \mathrm{mol} / \mathrm{L}$ on cell cycle progression induced by $10 \%$ NCS for $24 \mathrm{~h}$ in cultured vascular smooth muscle cells (VSMCs). Growth-arrested VSMCs were exposed to $0.1 \%$ NCS, $10 \%$ NCS, $10 \%$ $\mathrm{NCS}+10 \mu \mathrm{mol} / \mathrm{L}$ onychin or $10 \% \mathrm{NCS}+10 \mu \mathrm{mol} / \mathrm{L}$ genistein for $24 \mathrm{~h}$. Then cells were fixed with ethanol and incubated with PBS containing Rnase followed by staining with propidium iodide. Fluorescence was determined by using a flow cytometer. 
Table 1. Inhibitory effect of onychin on the proliferation of rat VSMCs induced by $10 \% \mathrm{NCS} . n=8$. Mean \pm SD. ${ }^{\mathrm{b}} P<0.05,{ }^{\mathrm{c}} P<0.01 v s 0.1 \% \mathrm{NCS}$ group. ${ }^{\mathrm{e}} \mathrm{P}<0.05$ vs $10 \%$ NCS group.

\begin{tabular}{|c|c|c|c|c|c|}
\hline & & \multicolumn{2}{|c|}{$10^{-7} \times$ Cell counts $/ \mathrm{mL}^{-1}$} & \multicolumn{2}{|c|}{ MTS measurement $(O D)$} \\
\hline & & $24 \mathrm{~h}$ & $48 \mathrm{~h}$ & $24 \mathrm{~h}$ & $48 \mathrm{~h}$ \\
\hline \multirow[t]{2}{*}{ Control } & $0.1 \% \mathrm{NCS}$ & $2.50 \pm 0.12$ & $2.50 \pm 0.05$ & $0.44 \pm 0.04$ & $0.44 \pm 0.04$ \\
\hline & $10 \% \mathrm{NCS}$ & $7.74 \pm 0.57^{\mathrm{c}}$ & $13.68 \pm 0.96^{\mathrm{c}}$ & $1.04 \pm 0.06^{\mathrm{c}}$ & $1.94 \pm 0.06^{\mathrm{c}}$ \\
\hline \multirow[t]{4}{*}{ Onychin } & $1 \mu \mathrm{mol} / \mathrm{L}$ & $7.32 \pm 0.24$ & $11.03 \pm 0.26$ & $0.93 \pm 0.04$ & $1.79 \pm 0.07$ \\
\hline & $5 \mu \mathrm{mol} / \mathrm{L}$ & $6.36 \pm 0.20^{\mathrm{e}}$ & $9.88 \pm 0.13^{\mathrm{e}}$ & $0.85 \pm 0.07^{\mathrm{e}}$ & $1.47 \pm 0.07^{\mathrm{e}}$ \\
\hline & $10 \mu \mathrm{mol} / \mathrm{L}$ & $5.46 \pm 0.51^{\mathrm{e}}$ & $8.58 \pm 0.56^{\mathrm{e}}$ & $0.64 \pm 0.05^{\mathrm{e}}$ & $1.21 \pm 0.05^{\mathrm{e}}$ \\
\hline & $50 \mu \mathrm{mol} / \mathrm{L}$ & $5.74 \pm 0.21^{\mathrm{e}}$ & $8.75 \pm 0.23^{\mathrm{e}}$ & $0.69 \pm 0.03^{\mathrm{e}}$ & $1.34 \pm 0.04^{\mathrm{e}}$ \\
\hline Genistein & $10 \mu \mathrm{mol} / \mathrm{L}$ & $5.58 \pm 0.75^{\mathrm{b}}$ & $8.71 \pm 0.45^{\mathrm{b}}$ & $0.67 \pm 0.06^{\mathrm{b}}$ & $1.27 \pm 0.06^{\mathrm{b}}$ \\
\hline
\end{tabular}

A

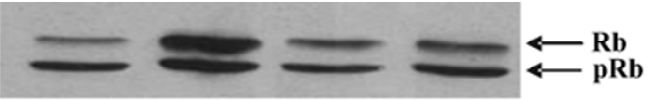

B

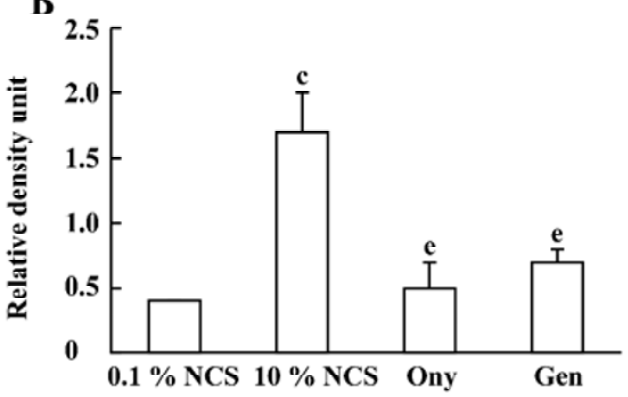

Figure 2. Inhibitory effect of onychin $10 \mu \mathrm{mol} / \mathrm{L}$ on phosphorylation of $\mathrm{Rb}$ induced by $10 \% \mathrm{NCS}$ ( $24 \mathrm{~h}$ ) in cultured vascular smooth muscle cells (VSMCs). A) Growth-arrested VSMCs were exposed to $0.1 \% \mathrm{NCS}, 10 \%$ $\mathrm{NCS}, 10 \% \mathrm{NCS}+10 \mu \mathrm{mol} / \mathrm{L}$ onychin or $10 \% \mathrm{NCS}+10 \mu \mathrm{mol} / \mathrm{L}$ genistein for $24 \mathrm{~h}$. Cells were harvested, and lysates were analyzed for Rb phosphorylation by Western blotting using anti-phosphor Rb antibodies. B) The relative expression of phosphorylated $\mathrm{Rb}$ over un-phosphorylated $\mathrm{Rb}$ was measured by using densitometry of autoradiograms in the linear range of film development. $n=3$ experiments. Mean \pm SD. ${ }^{\mathrm{c}} P<0.01$ vs $0.1 \%$ NCS group. ${ }^{\text {e }} P<0.05$ vs $10 \%$ NCS group.

tyrosine phosphorylation of ERK1/2, suggesting that onychin might be a potential inhibitor of tyrosine kinase (Figure 5).

\section{Discussion}

VSMC proliferation contributes to the remodeling of blood vessels and has been implicated in the pathogenesis of atherosclerosis. Phytoestrogens such as genistein can inhibit the proliferation of VSMC and have been implicated in the suppression of VSMC proliferation in neo-intima formation in vivo. Onychin, which has a similar structure to genistein, has been considered as a candidate for providing

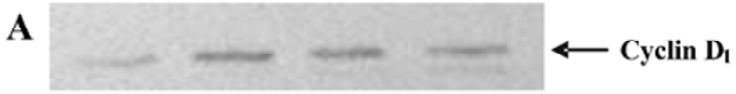

B

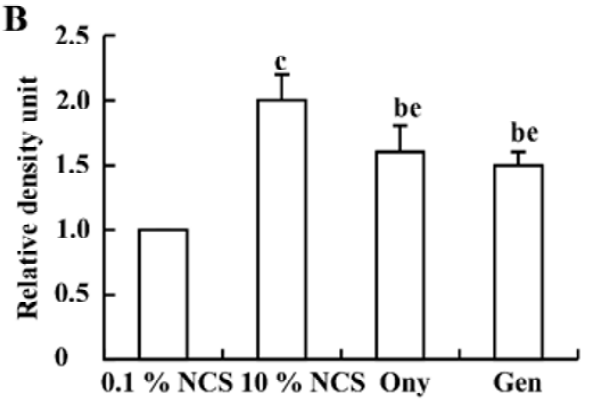

Figure 3. Inhibitory effect of onychin on cyclin $\mathrm{D}_{1}$ expression in cultured VSMCs. A) Growth-arrested VSMCs were exposed to $0.1 \% \mathrm{NCS}$, $10 \% \mathrm{NCS}, 10 \% \mathrm{NCS}+10 \mu \mathrm{mol} / \mathrm{L}$ onychin, or $10 \% \mathrm{NCS}+10 \mu \mathrm{mol} / \mathrm{L}$ genistein for $24 \mathrm{~h}$. Cells were harvested, and lysates were analyzed for cyclin $\mathrm{D}_{1}$ by using Western blotting. B) The relative expression of cyclin $\mathrm{D}_{1}$ was measured by using densitometry of autoradiograms in the linear range of film development. The results of each experiment were normalized to the density of the control $(0.1 \% \mathrm{NCS})$ sample, which was arbitrarily adjusted to 1.0 . The response to $10 \% \mathrm{NCS}$, and $10 \% \mathrm{NCS}+10$ $\mu \mathrm{mol} / \mathrm{L}$ onychin, $10 \% \mathrm{NCS}+10 \mu \mathrm{mol} / \mathrm{L}$ genistein was then determined on a relative basis. $n=3$ experiments. Mean \pm SD. ${ }^{\mathrm{b}} P<0.05,{ }^{\mathrm{c}} P<0.01$ vs $0.1 \%$ NCS group. ${ }^{\mathrm{e}} P<0.05$ vs $10 \% \mathrm{NCS}$

several cardiovascular protective effects ${ }^{[9-13]}$. To further investigate its actions in vascular biology, in the present study we studied the effect of onychin on the proliferation of rat VSMC induced by $10 \%$ NCS. The results showed that $1-50$ $\mu \mathrm{mol} / \mathrm{L}$ onychin inhibited the proliferation of VSMCs in a concentration-dependent manner, with a peak at $10 \mu \mathrm{mol} / \mathrm{L}$.

Proliferating cells pass through several cell cycle checkpoints, mainly the $G_{1}$ to $S$ and $G_{2}$ to $M$ transitions. The former checkpoint is considered to be the most important one in the replication of DNA and mitosis. We thus 

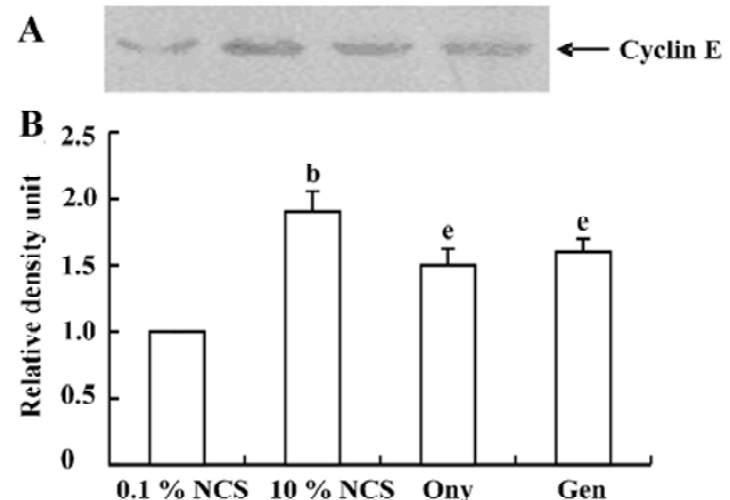

Figure 4. Inhibitory effect of onychin on cyclin E expression in cultured VSMCs. A. Growth-arrested VSMCs were exposed to $0.1 \% \mathrm{NCS}, 10 \%$ $\mathrm{NCS}, 10 \% \mathrm{NCS}+10 \mu \mathrm{mol} / \mathrm{L}$ onychin, or $10 \% \mathrm{NCS}+10 \mu \mathrm{mol} / \mathrm{L}$ genistein for $24 \mathrm{~h}$. Cells were harvested, and lysates were analyzed for cyclin $\mathrm{E}$ by Western blotting. B. The relative expression of cyclin E. The results of each experiment were normalized to the density of the control $(0.1 \% \mathrm{NCS})$ sample, which was arbitrarily adjusted to 1.0 . The response to $10 \% \mathrm{NCS}$, and $10 \% \mathrm{NCS}+10 \mu \mathrm{mol} / \mathrm{L}$ onychin, $10 \% \mathrm{NCS}+10 \mu \mathrm{mol} / \mathrm{L}$ genistein was then determined on a relative basis. $n=3$ experiments. Mean \pm SD. ${ }^{b} P<0.05$ vs $0.1 \%$ NCS group. ${ }^{\mathrm{e}} P<0.05$ vs $10 \%$ NCS group.

$\mathbf{A}$

IP: Anti-ERK1/2

IB: Anti-phosphor tyrosine
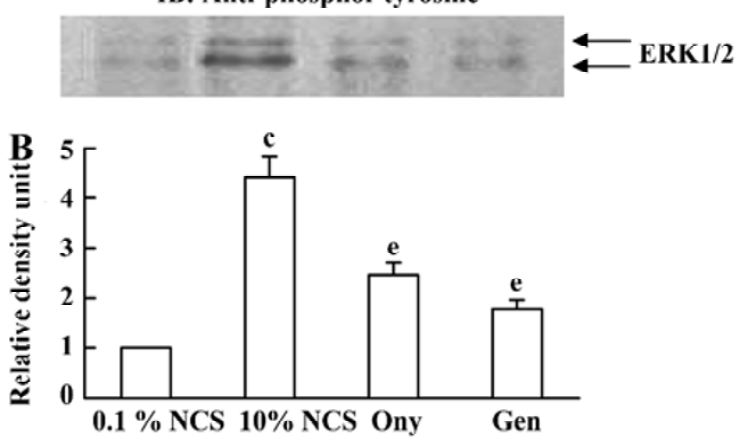

Figure 5. Inhibitory effect of onychin on the tyrosine phosphorylation of ERK $1 / 2$. A) Growth-arrested VSMCs were exposed to $0.1 \%$ NCS, $10 \%$ $\mathrm{NCS}, 10 \% \mathrm{NCS}+10 \mu \mathrm{mol} / \mathrm{L}$ onychin, or $10 \% \mathrm{NCS}+10 \mu \mathrm{mol} / \mathrm{L}$ genistein for $20 \mathrm{~min}$. Cells lysates were immunoprecipitated with anti-ERK1/2 antibody, and Western blotting was performed with anti-phospho tyrosine antibodies. IP: immunoprecipitation; IB: immunoblot. B) The relative expression of tyrosine phosphorylation in ERK1/2 was measured by using densitometry of autoradiograms in the linear range of film development. The results of each experiment were normalized to the density of the control ( $0.1 \% \mathrm{NCS})$ sample, which was arbitrarily adjusted to 1.0 . The response to $10 \% \mathrm{NCS}, 10 \% \mathrm{NCS}+10 \mu \mathrm{mol} / \mathrm{L}$ onychin, and $10 \% \mathrm{NCS}+10 \mu \mathrm{mol} / \mathrm{L}$ genistein was then determined on a relative basis. $n=3$ experiments. Mean \pm SD. ${ }^{\mathrm{c}} P<0.01$ vs $0.1 \%$ NCS group. ${ }^{\mathrm{e}} P<0.05$ vs $10 \%$ NCS group. logically speculate that onychin affects VSMC proliferation via alterations in the cell cycle progression. Indeed our data show that onychin blocks cell cycle progression at the $G_{1}$ transition and stops VSMCs entering the S phase from $\mathrm{G}_{0}$ $\mathrm{G}_{1}$, consequently inhibiting the replication of DNA and the growth of VSMCs.

$\mathrm{Rb}$ is a key modulator of cell-cycle transit because of its ability to control the $\mathrm{G}_{1} / \mathrm{S}$-phase transition ${ }^{[17]}$. Rb activity is related to its ability to modulate the activation of the $E_{2} F$ family, which are required for S-phase progression ${ }^{[18]}$. Cell cycle progression from $G_{1}$ to $S$ phase is usually accompanied by $\mathrm{Rb}$ phosphorylation, which is induced by the cyclin $\mathrm{D}_{1}-\mathrm{CDK}_{4}$ and the cyclin E-CDK${ }_{2}$ complexes in the late $\mathrm{G}_{1}$ phase. $\mathrm{Rb}$ phosphorylation leads to $\mathrm{E}_{2} \mathrm{~F}$ release. Conversely, hypophosphorylated $\mathrm{Rb}$ sequesters $\mathrm{E}_{2} \mathrm{~F}$ and prevents transcription of the $\mathrm{E}_{2} \mathrm{~F}$ target genes. Recent evidence indicates that phosphorylated $\mathrm{Rb}(\mathrm{pRb})$ inactivation is a key molecular event leading to $S$-phase commitment at the $\mathrm{G}_{1}$ restriction point in the cell cycle ${ }^{[19]}$. Therefore, deregulating $\mathrm{pRb}$ inactivation in the $G_{1}$ phase becomes a universal mechanism underlying cellular transformation. Recently, Chang et al. showed that a nonphosphorylatable, constitutive active form of murine $\mathrm{Rb}$ inhibited VSMC proliferation and reduced neointima formation in injured rat carotid arteries and porcine femoral artery models ${ }^{[20]}$. Growth factors such as platelet-derived growth factor, epidermal growth factor, and fibroblast growth factor have been shown to induce Rb phosphorylation in quiescent cells entering into the cell cycle ${ }^{[21]}$. In light of this broad spectrum of activity, $\mathrm{Rb}$ is a strong candidate for use as an anti-proliferative agent in a number of disorders that are characterized by inappropriate proliferate responses. To test the possible effects of onychin on $\mathrm{Rb}$ phosphorylation, we observed the relative amounts of hypophosphorylated and phosphorylated forms of $\mathrm{Rb}$ in VSMCs by using Western blotting. The results showed that onychin decreased the phosphorylation levels of $\mathrm{Rb}$.

Progression through the mammalian mitotic cycle is coordinated by expression and/or activation of multiple holoenzymes composed of a catalytic cyclin-dependent kinase (CDK) and a cyclin-regulatory subunit ${ }^{[22]}$. Different cyclin/ CDK complexes are temporally activated at specific phases of the cell cycle. Progression through the first gap phase $\left(\mathrm{G}_{1}\right)$ requires cyclin D-dependent kinase $\left(\mathrm{CDK}_{4}\right.$ and $\left.\mathrm{CDK}_{6}\right)$ and cyclin $\mathrm{E} / \mathrm{CDK}_{2}$ activity ${ }^{[22,23]}$, which results in $\mathrm{Rb}$ hyperphosphorylation. The association of $\mathrm{CDK}_{4}$ or $\mathrm{CDK}_{6}$ with D-type cyclins is critical for G1 phase progression, whereas the $\mathrm{CDK}_{2}$-cyclin E complex is important for initiation of the $\mathrm{S}$ phase. It has been reported that administration 
of genistein in rats with an acute renal injury decreases ERK activation and cyclin $\mathrm{D}_{1}$ expression ${ }^{[24]}$. It has been reported that exposure of VSMC to $10 \%$ FCS causes a time-dependent increase in cyclin D1 and cyclin $\mathrm{E}^{[25]}$. In the present study, we also found that $10 \%$ FCS up-regulated the expression of cyclin $\mathrm{D}_{1}$ and cyclin $\mathrm{E}$, and onychin treatment inhibited the effects of NCS.

The MAPK family constitutes a major ubiquitous intracellular signaling system involved in the regulation of cell growth, differentiation, and survival ${ }^{[26]}$. To date, at least three distinct mammalian MAPKs have been characterized: the extracellular-regulated kinases (ERKs), Jun N-terminal kinases/ stress-activated protein kinase (JNK/SAPK) and p38. Among of them, the mammalian ERKs (ERK1/p44 and ERK2/p42) are generally thought to play a role in cell proliferation and differentiation. ERK1/2 is serine/threonine kinase, which is activated by phosphorylation at both threonine and tyrosine residues. Evidence indicates that phosphorylation of the residues Thr 202/Tyr 204 (for human ERK, or Thr 185/Tyr 187 for bovine ERK) in the conserved Thr/Glu/Tyr ERK sequences is necessary and sufficient for full activation of these enzymes and serves as an indicator of their activation status $^{[27]}$. In our experiments, we observed an obvious tyrosine phosphorylation of ERK $1 / 2$ in the $10 \%$ NCS group. Onychin, like genistein, markedly declined the phosphorylation level of tyrosine of ERK1/2.

In summary, onychin inhibits the proliferation of VSMCs through $\mathrm{G}_{1}$ phase cell cycle arrest by decreasing the tyrosine phosphorylation of ERK1/2, decreasing the expression of cyclin $\mathrm{D}_{1}$ and cyclin $\mathrm{E}$, and sequentially inhibiting $\mathrm{Rb}$ phosphorylation.

\section{Acknowledgement}

The authors are indebted to Dr He-sheng OU (University of Chicago) for his critical discussion suggestions, and valuable help in the preparation of this manuscript.

\section{References}

1 Lin MW, Roubin GS, King SB III. Restenosis after coronary angioplasty. Potential biologic determinants and role of intimal hyperplasia. Circulation 1989; 79: 1374-87.

2 Ohlstein EH, Douglas SA, Sung CP, Yue T, Louden C, Arleth A, et al. Carvedilol, a cardiovascular drug, prevents vascular smooth muscle cell proliferation, migration, and neointimal formation following vascular injury. Proc Natl Acad Sci USA 1993; 93: 6189-93.

3 Corsini A, Bernini F, Quarato P, Donetti E, Bellosta S, Fumagalli R, et al. Non-lipid-related effects of 3-hydroxy-3-methylglutaryl coenzyme A reductase inhibitors. Cardiology 1996; 87: 458-68.

4 Bennett MR, Anglin S, McEwan JR, Jagoe R, Newby AC, Evan GI.
Inhibition of vascular smooth muscle cell proliferation in vitro and in vivo by c-myc antisense oligodeoxy-nucleotides. J Clin Invest 1994; 93: 820-8.

5 Pan W, Ikeda K, Takebe M, Yamori Y. Genistein, daidzein and glycitein inhibit growth and DNA synthesis of aortic smooth muscle cells from stroke-prone spontaneously hypertensive rats. J Nutri 2001; 131: 1154-8.

6 Polkowski K, Mazurek AP. Biological properties of genistein. A review of in vitro and in vivo data. Acta Pol Pharm 2000; 57: 13555.

7 Wang HK. The therapeutic potential of flavonoids. Expert Opin Investig Drugs 2000; 9: 2103-19.

$8 \mathrm{Xu} \mathrm{YL}$, Isao K, Ma YB. Acytotoxic flavanone glycoside from onychiun japonicum: structure of onychin. Phytochemistry 1993; 33: 510-1.

9 Tuo QH, Huang HL, Xie ZZ. Protection of onychin on injury of endothelium-dependent relaxion induced by lysophosphatidylcholine. Chin J Arterioscler 2001; 9: 27-30.

10 Tuo QH, Liao DF, Zhu BY, Yan FX. Protective effects of onychin on vascular endothelial cell injured by oxidative stress. Chin J Clin Pharmacol Ther 2003; 8: 381-4

11 Guo Y, Zhu BY, Yan FX, Liao DF. Protective action of onychin against growth inhibition of endothelial cell injured by oxidation and its mechanism. Chin Pharmacol Bull 2003; 19: 401-3.

12 Guo Y, Zhu BY, Yan FX, Huang HL, Liao DF. Protective effects of onychin on the human umbilical vein endothelial cell injured by menadione. Chin J Pathophysiol 2003; 19: 10-3.

13 Tuo QH, Wang C, Yan FX, Liao DF. MAPK pathway mediates the protective effects of onychin on oxidative stress-induced apoptosis in ECV304 endothelial cells. Life Sci 2004; 76: 487-97.

14 Tu YS, Huang HL, Zhu BY, Liao DF. Enzymatic dispersion method of primary culture of rat aortic vascular smooth muscle cells. Chin J Arterioscler 2001; 9: 438-40.

15 Liao DF, Monia B, Dean N, Berk BC. Protein kinase C- $\zeta$ mediates angiotensin II activation of ERK1/2 in vascular smooth muscle cells. J Biol Chem 1997; 272: 6146-50.

16 Liao DF, Jin ZG, Baas AS, Daum G, Gygi SP, Aebersold R, et al. Purification and identification of secreted oxidative stress-induced factors from vascular smooth muscle cells. J Biol Chem 2000; 275 : 189-96.

17 Goodrich DW, Lee WH. Molecular characterization of the retinoblastoma susceptibility gene. Biochim Biophys Acta 1993; 1155: 4361.

18 Hiebert SW. Regions of the retinoblastoma gene product required for its interaction with the $\mathrm{E}_{2} \mathrm{~F}$ transcription factor are necessary for $\mathrm{E}_{2}$ promoter repression and $\mathrm{pRb}$-mediated growth suppression. Mol Cell Biol 1993; 13: 3384-91.

19 King KL, Cidlowski JA. Cell cycle regulation and apoptosis. Annu Rev Physiol 1998; 60: 601-17.

20 Chang MW, Barr E, Seltzer J, Nabel GJ, Nabel GJ, Parmacek MS, et al. Cytostatic gene therapy for vascular proliferative disorders with a constitutively active form of the retinoblastoma gene product. Science 1995; 267: 518-22.

21 Slansky JE, Farnham PJ. Introduction to the $\mathrm{E}_{2} \mathrm{~F}$ family: protein structure and gene regulation. Curr Top Microbiol Immunol 1996; 208: $1-30$.

22 Sherr CJ. $G_{1}$ phase progression: cycling on cue. Cell 1994; 79: 551-5.

23 Lu B, Dai YM. Abnormal cycle regulation of cells in the HCC. World 
J Gastroenterol 2001; 9: 205-8.

24 Ishizuka S, Yano T, Hagiwara K, Sone M, Nihei H, Ozasa H, et al. Extracellular signal-regulated kinase mediates renal regeneration in rats with myoglobinuric acute renal injury. Biochem Biophys Res Commun 1999; 254: 88-92.

25 Kronemann N, Nockher WA, Busse R, Schini-Kerth VB. Growthinhibitory effect of cyclic GMP- and cyclic AMP-dependent vasodi- lators on rat vascular smooth muscle cells: effect on cell cycle and cyclin expression. Br J Pharmacol 1999; 126: 349-57.

26 Seger R, Krebs EG. The MAPK signaling cascade. FASEB J 1995; 9: 726-35.

27 Huang CY, Ferrell JE Jr. Ultrasensitivity in the mitogen-activated protein kinase cascade. Proc Natl Acad Sci USA 1996; 93: 1007883.

\section{5th International Congress of Physiological Sciences}

2005 Mar 31-Apr 5

San Diego CA, USA

\section{Experimental Biology 2005 Meeting}

2005 Apr 2 - Apr 6 San Diego CA, USA

One registration fee providing access to both meetings! IUPS Travel Award Application Deadline - 2004 Nov 1 Abstract Submission Deadline - 2004 Nov 3

Early Registration Deadline - 2005 Feb 4

Housing Deadline - 2005 Feb 21

Please visit

http://www.iups2005.org/announce/travel_grants.htm

Please contact

Martin Frank, $\mathrm{PhD}$

Executive Director

American Physiological Society

9650 Rockville Pike, Bethesda, MD 20814-3991

Phn 301-634-7118 Fax 301-634-7242

E-mailmfrank@The-APS.org 